\title{
Temperature-dependent adverse effects of drifting macroalgae on the survival of Manila clams in a eutrophic coastal lagoon
}

\author{
Yasushi Miyamoto ${ }^{1, *}$, Katsumasa Yamada ${ }^{2}$, Keisuke Hatakeyama $^{3} \&$ \\ MASAMI HAMAGUCHI ${ }^{4}$ \\ ${ }^{1}$ Fukui Prefectural Satoyama-Satoumi Research Institute, 122-31-1 Torihama, Wakasa, Mikatakaminaka, Fukui 919-1331, Japan \\ ${ }^{2}$ Marine Science Laboratory, Centrer for Water Cycle, Marine Environment and Disaster Management, Kumamoto University, \\ 2-39-1 Kurokami, Chuo-ku, Kumamoto 860-8555, Japan \\ ${ }^{3}$ Environmental Sanitation Research Center, 526-1 Minamidani, Yurihama, Tottori 682-0704, Japan \\ ${ }^{4}$ National Research Institute of Fisheries and Environment of Inland Sea, Fisheries Research Agency, 2-17-5 Maruishi, Hatsu- \\ kaichi, Hiroshima 739-0452, Japan
}

Received 11 April 2017; Accepted 30 August 2017 Responsible Editor: Shigeaki Kojima

\begin{abstract}
The proliferation of drifting macroalgae and the accompanying occurrence of the impoverishment of zoobenthic species has become a major problem worldwide. We examined the temperature dependency of the effects of macroalgae on the survival of Manila clams in Nakaumi Lagoon in western Japan. We conducted (i) semi-monthly field surveys to clarify seasonal changes in macroalgal abundance and clam density and (ii) 7-day macroalgal enclosing and excluding experiments in two temperature settings (mean water temperatures: 19 and $29^{\circ} \mathrm{C}$ ) to test temperature-induced differences in algal effects on bottom-water redox conditions and clam survival. Clam density decreased during summer (July-September), when increased coverage and thickness of drifting macroalgae was observed. In contrast, clam density increased from autumn to spring as macroalgal abundance decreased. Further, reducing conditions $($ Eh $<0)$ were only detected in bottom waters in the presence of macroalgae during summer (water temperature $>29^{\circ} \mathrm{C}$ ), suggesting that drifting macroalgae induced hypoxia under summer temperatures and consequently led to clam mortality. The 7-day algal enclosure experiment resulted in reducing bottom water conditions when mean water temperature was $29^{\circ} \mathrm{C}$. Further, clam survival decreased in the algal enclosure at $29^{\circ} \mathrm{C}$, whereas no such changes were detected at $19^{\circ} \mathrm{C}$. These results indicate that the effects of drifting macroalgae on the geochemical environment and clam survival are temperature dependent; therefore, global warming may enhance the likelihood of macroalgae-induced hypoxia with its associated adverse consequences in marine life.
\end{abstract}

Key words: Drifting macroalgae, Hypoxia, Manila clam, Ruditapes philippinarum, Temperature dependency

\section{Introduction}

Drifting macloalgal mats are conglomerates of opportunistic, ephemeral algae that have detached from the parent algal area and accumulate in mats of varying sizes (Arroyo \& Bonsdorff 2016). Drifting algal mats in temperate coastal waters are becoming an increasingly common phenomenon along the world's shorelines as a result of coastal eutrophication (Fletcher 1996, Valiela et al. 1997, Norkko et al. 2000, Marsden \& Bressington 2009, Ye et al.

*Corresponding author: Yasushi Miyamoto; E-mail, scapharca@gmail.com
2011, Gubelit 2015). For instance, the coastline of the Yellow Sea experienced the world's largest green tide in 2008 that comprised more than 1 million tons of algal biomass (Ulva prolifera Mueller) and covered an area of 13,000$30,000 \mathrm{~km}^{2}$ (Leliaert et al. 2008, Sun et al. 2008, Liu et al. 2013). This so-called "largest macroalgal bloom" occurred in areas far away from the cultivation (i.e., parent) area due to its buoyant nature (Liu et al. 2009). Further, in 2011, there was an ocean-scale accumulation of Sargassum spp., which, at its peak, drifted across the Atlantic resulting in massive golden tides (i.e., blooms of drifting brown algae) along the West African coast and on the opposite side of 
the Atlantic (Smetacek \& Zingone 2013). In addition to these events, the number of reports on macroalgal blooms from new locations all over the world increased during the 2000s (Ye et al. 2011).

In high nutrient environments, drifting macroalgae can proliferate rapidly (Valiela et al. 1997, Burkholder et al. 2007), causing diel-cycling hypoxia as photosynthesis raises dissolved oxygen (DO) content during the day and cellular respiration in the absence of photosynthesis depletes oxygen at night (D’Avanzo \& Kremer 1994, D'Avanzo et al. 1996, Hauxwell et al. 2001, Berglund et al. 2003). In consequence, a cycle develops whereby algae grow until they are overshaded, die, and decompose, resulting in sustained hypoxia (Coffin et al. 2017). This macroalgae-induced hypoxia can affect the geochemical environment, organismal behavior, and survival. Alterations in redox conditions imposed by macroalgae increase toxic sulfide concentrations as DO concentration decreases and sulfate is microbially reduced (Lavery \& McComb 1991, Krause-Jensen et al. 1999, Auffrey et al. 2004). This alteration has deleterious effects, particularly on benthic sessile organisms such as sediment-dwelling bivalves (Norkko \& Bonsdorff 1996a, 1996b, 1996c, Arroyo et al. 2012) and eelgrass (Hauxwell et al. 2001, Hauxwell \& Valiela 2004). Based on a field experiment, Norkko \& Bonsdorff (1996b) estimated that 1 ha of uncovered bare sand sustains 242 million individuals and $1 \mathrm{t}$ of benthic macrofauna, whereas 1 ha of sand with drifting algal cover sustains only 31 million individuals and $7 \mathrm{~kg}$ of macrofauna. This suggests that drifting macroalgae play an important role in structuring benthic communities on shallow, sandy bottom habitats in the northern Baltic Sea.

The adverse effects of drifting macroalgae are seasonal phenomena (Norkko \& Bondsdorf 1996a). The maximum occurrence of drifting macroalgae often coincides with the most productive summer season which corresponds with the recruitment period of many benthic invertebrates, hence linking drifting algae to mass mortality events (Norkko \& Bondsdorf 1996a). However, the seasonal occurrence of drifting macroalgae may not be the only reason for the summer detrimental effects. Indeed, oxygen dynamics in macroalgae-dominated ecosystems strongly depend on water temperature, with lower DO at higher summer temperatures owing to accelerated metabolic rates (Vaquer-Sunyer et al. 2012). Additionally, Tyler et al. (2009) reported that variation in the duration and spatial extent of algae-induced hypoxia was better explained by water temperature than other environmental variables (i.e., insolation, precipitation, streamflow, tide, and wind), with longer periods of hypoxia occurring at higher temperatures. These suggest that the seasonal adverse effects of algae-induced hypoxia can be triggered by a set of mechanisms (i.e., temperature-dependent DO dynamics and seasonal occurrence of drifting macroalgae). However, to date, these mechanisms have not been explicitly separated. Considering on-going global warming (IPCC 2013),

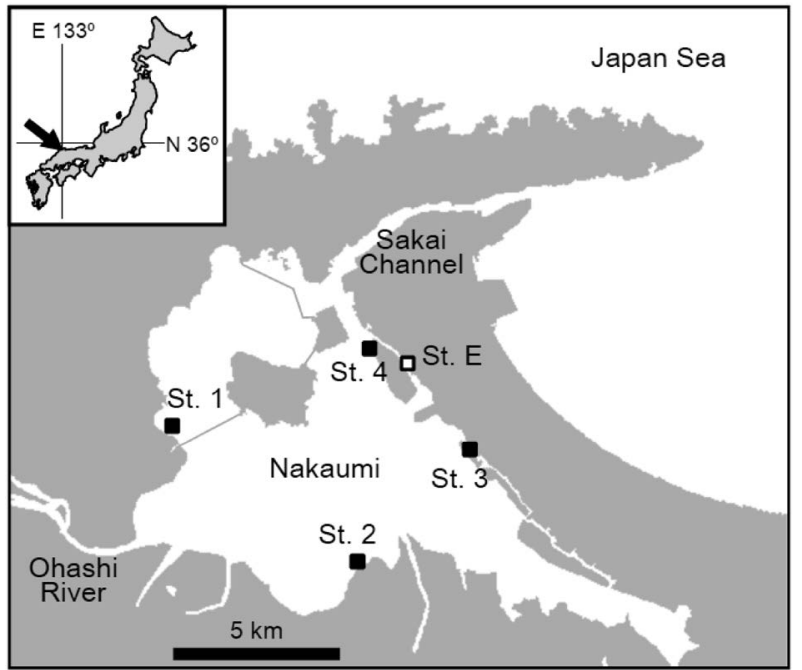

Fig. 1. Map of Nakaumi Lagoon. Census sites (Site 1-4) and experimental site (Site E) are shown.

separating the driving factors, in particular evaluating the temperature-dependency of macroalgae-induced hypoxia, is essential to establishing management strategies to adapt to its potentially negative impacts on coastal ecosystems.

Recently, in the eutrophic coastal Nakaumi Lagoon in western Japan (Fig. 1), beaching and accumulation of drifting macroalgae became a serious problem. Such semi-enclosed, hydrologically stagnant environments are likely to accumulate drifting macroalgae and retain algaeinduced hypoxia for long periods of time. In fact, macroalgal blooms during the summer months and associated massive die-offs of dominant zoobenthos, such as Asian mussels (Musculista senhousia (Benson in Cantor 1842)) and Manila clams (Ruditapes philippinarum (Adams \& Reeve 1850)) dwelling in the coastal shallow zones above the halocline, have been reported (Fujikawa et al. 2000, Yamada et al. 2014). The Manila clam, in particular, appears to be sensitive to algae-induced hypoxia because the clam is an infaunal species that often experiences high mortality caused by the deleterious effects of drifting macroalgae (Everett 1991, Norkko \& Bondsdorf 1996a, 1996b). To date, summer mortalities of Manila clams in Nakaumi Lagoon are speculated to result from macroalgae-induced hypoxia on the basis of field observations (Yamada et al. 2014); however, direct experimental evidence of the deleterious effects of drifting macroalgae and its temperature dependency have not been presented. Further, the seasonal dynamics of drifting macroalgae have not yet been documented in the lagoon.

The purpose of this study was to determine whether drifting macroalgae caused mortality in Manila clams in a temperature-dependent manner in Nakaumi Lagoon. First, we clarified seasonal changes in macroalgal abundance and clam density by conducting semi-monthly field surveys. Second, we experimentally assessed whether the effects of drifting macroalgae on bottom water redox conditions and 
the clam's survival differed in a temperature-dependent manner. In the field experiments, we compared the effects of drifting macroalgae at two different water temperatures (mean temperatures: 29 and $19^{\circ} \mathrm{C}$ in August and October, respectively), as previous literature indicated that occurrence of algae-induced hypoxia was reported when the water temperature was $\sim 25^{\circ} \mathrm{C}$ but not when the temperature was $\sim 20^{\circ} \mathrm{C}$ in situ (D’Avanzo \& Kremer 1994).

\section{Materials and Methods}

\section{Study site}

The study was conducted in coastal shallow areas (depth: $\sim 1 \mathrm{~m}$ ) in the semi-closed coastal Nakaumi Lagoon in western Japan (area: $86.8 \mathrm{~km}^{2}$, mean depth: $5.4 \mathrm{~m}$ ). Seawater enters from the northeast strait (Sakai Channel) and river water mostly flows in from the southeast river (Ohashi River, Fig. 1). Because of its semi-closed location, the two bodies of water form a density stratification at a depth of 3-4 m during summer, often resulting in summer hypoxia (even anoxia) and sulfidic conditions in the hypolimnion (Sakai et al. 2013). In contrast, the upper water column is saturated with DO because of atmospheric gas exchange and a high rate of primary production (Sakai et al. 2013). The salinity of the epilimnion fluctuates widely (6-20), whereas fluctuation in the hypolimnion is relatively small (27-32). The annual tidal range is within $20 \mathrm{~cm}$ (Yamamuro et al. 2000).

Extensive proliferation of ephemeral macroalgae has been reported from the lagoon in recent years (Fujikawa et al. 2000, Miyamoto \& Hatsuda 2007, Yamada et al. 2014), likely because of cultural eutrophication. The drifting algal mat mainly appeared in coastal shallow zones above the halocline (depth $\leq 3 \mathrm{~m}$ ) during the summer period (Miyamoto \& Hatsuda 2007, Yamada et al. 2014). The algal mat was comprised of a conglomerate of several species of filamentous ephemeral algae (e.g., Chaetomorpha crassa (C. Agardh) Kuetzing, Cladophora sp., U. prolifera, and Gracilaria vermiculophylla (Ohmi) Papenfuss) (Miyamoto \& Hatsuda 2007), which has increased worldwide in recent years (Fletcher 1996, Valiela et al. 1997, Hauxwell \& Valiela 2004, Smetacek \& Zingone 2013). In Nakaumi Lagoon, macroalgae (particularly G. vermiculophylla) were harvested as a source of agar until the 1970s, with an annual maximum harvest (7,300 t) recorded in 1960 (Moriwaki \& Michine 2007). Macroalgae were also used as organic fertilizers (Yamamuro et al. 2006). However, the harvest decreased in later years and ended in the late 1970s (Moriwaki \& Michine 2007). The decline in harvesting activities may also have contributed to recent blooms of the ephemeral macroalgae.

The Manila clam ( $R$. philippinarum) is indigenous to the Pacific coast of Asia (Tezuka et al. 2012), and is one of the dominant zoobenthos in the lagoon (Yasugi et al. 1999, Yamaguchi et al. 2013) inhabiting shallow sandy flats. In the coastal Nakaumi Lagoon, clam density varied seasonally, increasing in the spring because newly settled clams spawned during the previous autumn and decreasing in the following summer (Yamada et al. 2014). Annual catch yields amounted to $700-800 \mathrm{t}$ during the 1960s-1970s; however, the yields have decreased to $20-30 \mathrm{t}$ since the 1980s (Moriwaki \& Michine 2007).

\section{Seasonal changes in abundance of macroalgae, Manila clams, and the environment}

To investigate the temporal dynamics of macroalgal abundance, we set up $10 \times 10 \mathrm{~m}$ permanent quadrats divided into 1,600 subquadrats $(25 \times 25 \mathrm{~cm})$ at a depth of $\sim 1 \mathrm{~m}$ at 4 randomly selected topologically homogeneous sandy areas (mud content $<20 \%$ ) (Sts. 1-4, Fig. 1). Algal percent cover was visually determined as relative cover $(5$ levels: $0,25,50,75,100 \%$ ) in each sub-quadrat; wholequadrat coverage was calculated by adding together each sub-quadrat percent cover value and dividing that number by the total number of quadrats observed. Further, macroalgal mat thickness was determined as the distance from the top to the bottom surface of the algal mat using a plastic scale, taking 20 measurements at random within the permanent quadrats. These observations were conducted monthly from May 2012 to May 2013, with the exceptions of the winter months (December and February) because of low macroalgal abundance.

In conjunction with the macroalgal census, we conducted quantitative benthic surveys in order to determine seasonal variations in Manila clam density. At each site (Sts. 1-4, Fig. 1), we collected 5 replicate sediment samples by excavating a quadrat $(20 \times 20 \mathrm{~cm}$ quadrat with $15 \mathrm{~cm}$ depth). The sediment samples were taken from the surrounding areas of the permanent quadrats for the algal census to keep macroalgae within the quadrat undisturbed. Sediment samples were sieved using a $1 \mathrm{~mm}$ mesh sieve and preserved in $70 \%$ ethanol. In the laboratory, the samples were sorted and Manila clams were identified, counted, and measured (shell length, $\mathrm{mm}$ ).

To clarify seasonal changes in the abiotic environment, temperature and salinity in bottom waters were recorded using water quality multi-probes (Hydrolab DS5, OTT Hydromet, Loveland, CO, USA) at each site. Additionally, to extrapolate our snapshot data, continuously monitored data taken at 1-h intervals for temperature and salinity (see Figs. 2A, B) were downloaded from a website (Water Information System) managed by the Japanese Ministry of Land, Infrastructure, Transportation, and Tourism (http:// wwwl.river.go.jp/). The data were collected at a depth of $0.5 \mathrm{~m}$ at the center of Nakaumi Lagoon.

To confirm temperature dependency of redox conditions in bottom waters, oxidation-reduction potentials (ORP, $\mathrm{mV}$ ) and water temperatures were measured monthly between June 2012 and May 2013 with the exception of winter months (December and February) at each site at the sediment surface in algae-covered and uncovered areas 

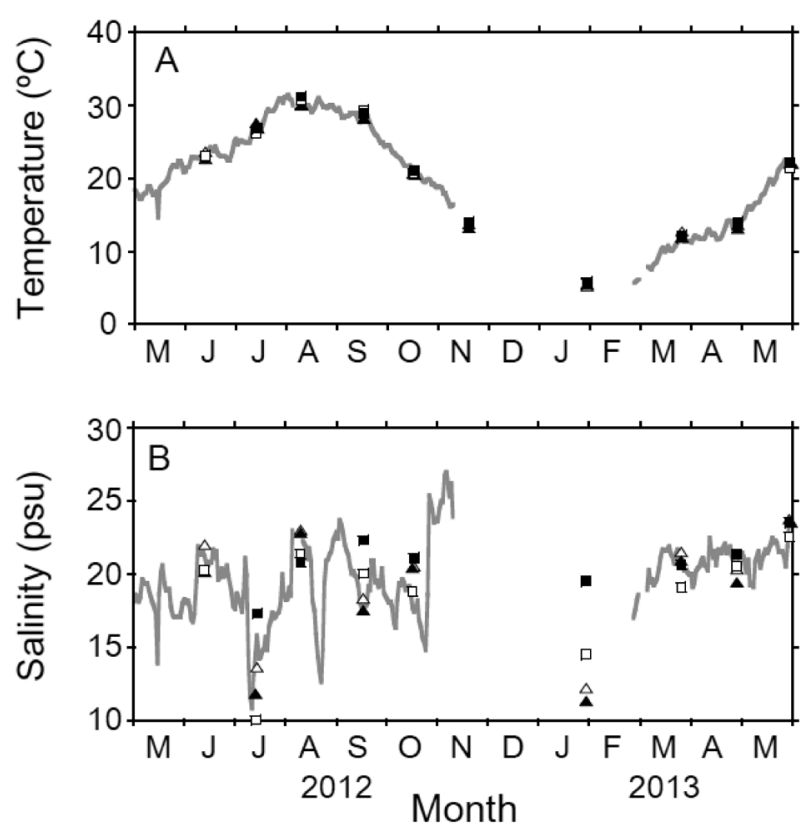

- St. 1 \&t.2 2 St. $3 \Delta$ St. $4-$ Center of Nakaumi

Fig. 2. Seasonal changes in temperature (A) and salinity (B) in each census site and at the center of Nakaumi Lagoon.

(Sts. 1-4, Fig. 1). Water samples of $20 \mathrm{~mL}$ were carefully taken with glass syringes by scuba diving, from near the bottom ( $\sim 1 \mathrm{~cm}$ above sediment surface) on algae-covered and uncovered areas. After the water samples were collected, ORP and temperatures were measured with an ORP meter (RM-20P, DKK-TOA Inc., Tokyo, Japan) by inserting the sensor probe into the syringe containing a water sample. The ORP and water temperatures were determined on board our support vessel within 5 min of collection to reflect the ambient bottom environment. The measurement was replicated 3 times at each site.

To test whether the variation in Manila clam density can be explained by macroalgal abundance during the algae growing season (Jun-Oct, Fig. 3), we examined the relationship between the density (dependent variable), algal abundance (coverage, algal-mat thickness; explanatory variables) and environmental variables (water temperature, salinity; explanatory variables) using generalized linear mixed-effect models (GLMMs), assuming the random effect varies among sites and months. Log-link and Poisson error distribution were adopted to model clam density. Akaike information criteria (AIC) were calculated to rank models. The GLMMs were performed with the package "Ime4 ver 1.1-12" in R 3.3.3 (R Core Team 2017).

\section{Temperature dependency of algae-induced clam mortal- ity and environmental variables}

In August and October 2012, corresponding to the peak and late macroalgae-growing season, respectively (Figs. $3 \mathrm{~A}, \mathrm{~B})$, the effect of drifting macroalgae on Manila clam survival was evaluated on a sandy flat (St. E, Fig. 1) at
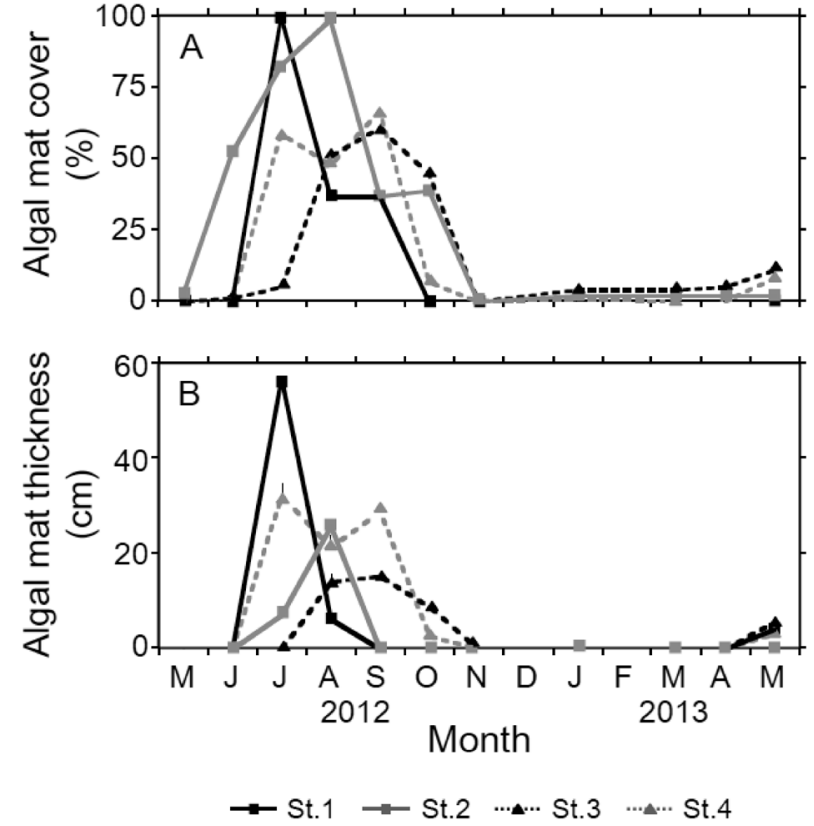

Fig. 3. Seasonal changes in macroalgal cover (A) and thickness of the macroalgal mats (B) in each census site. Error bars in Fig. 3B are $+1 \mathrm{SE}(\mathrm{n}=20)$.

$\sim 1 \mathrm{~m}$ depth over 7 days. The water temperatures in each experiment were $29.0 \pm 0.73$ (mean \pm SE) and $18.9 \pm 0.50^{\circ} \mathrm{C}$ ( $n=168$ each: 1 - $\mathrm{h}$ interval monitoring) in August and October, respectively. The locality chosen represented a topologically homogeneous area which had not been subject to long-term exposure by drifting algal mats on a basis of pre-observation. However, some short-term exposure could not be ruled out because of unpredictable algal movements. Two plastic-mesh fences (mesh size: $2 \mathrm{~cm}$ ) measuring $1 \times 1 \mathrm{~m}$ area and $1 \mathrm{~m}$ height, one for enclosing drifting algae and the other for excluding algae (control), were placed on the bottom and anchored with iron pegs at the 4 corners, $1 \mathrm{~m}$ apart. The $2-\mathrm{cm}$ mesh fencing was small enough to retain or exclude macroalgae, but large enough so that water exchange was not significantly reduced (velocity within cage: $1.5 \pm 0.23 \mathrm{~cm} \mathrm{sec}^{-1}$; without cage: $1.9 \pm 0.36 \mathrm{~cm} \mathrm{sec}^{-1}$; $\mathrm{t}$-test $=0.99, \mathrm{p}=0.35$ ). Five experimental blocks containing the algal enclosure and exclosure were set up. At the center of the bottom of each fencing area, a plastic mesh-basket measuring $30 \times 23 \times 5 \mathrm{~cm}$ (mesh size: $20 \mathrm{~mm}$ ) containing 20 clams each was buried into the sediment at $5 \mathrm{~cm}$ depth and covered by stainless mesh (mesh size: $1 \mathrm{~cm}$ ). The top face of the basket was placed at the surface of the sediment. The Manila clams used in this experiment were collected by scuba diving from surrounding areas. All clams used were 10 to $20 \mathrm{~mm}$ in shell length (mean \pm SE: $15.6 \pm 0.1 \mathrm{~mm}, \mathrm{n}=400$ ), which is representative of the size-class from the summer to the autumn in Nakaumi Lagoon (Yamada et al. 2014, Fig. 4B). The macroalgae used in the algal enclosure were collected with a sledge from surrounding areas. The col- 
lected algal mats were conglomerates of Cladophora sp., $U$. prolifera, and G. vermiculophylla for both the summer and autumn experiments. Collected algae were carefully rinsed with seawater before use to remove macrofauna. Around $30 \mathrm{~cm}$ thickness of drifting macroalgae $(\sim 4,700 \mathrm{~g}$ wwt) was placed into the algae enclosure after clams had been placed. The thickness is comparable to that of naturally occurring drifting macroalgae during the summer $(32.1 \pm 2.8 \mathrm{~cm}, \mathrm{n}=80)$, when the macroalgae proliferate
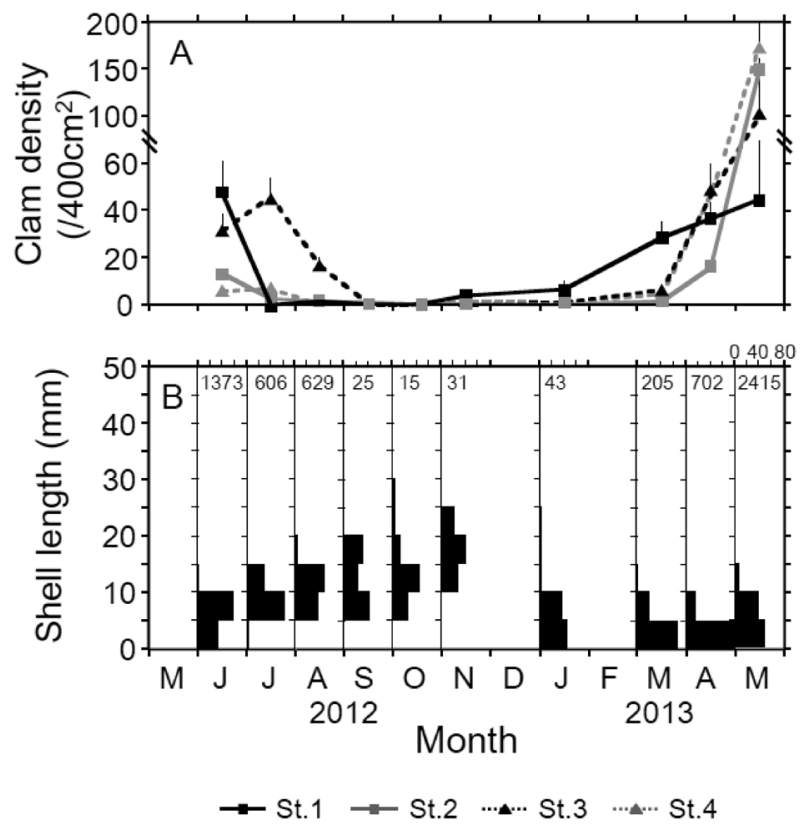

Fig. 4. Seasonal changes in Manila clam density in each census site (A) and shell-length distribution of the clam (B). Error bars in Fig. $4 \mathrm{~A}$ are $+1 \mathrm{SE}(\mathrm{n}=5)$. The numbers of individuals in each month are shown above each histogram. most abundantly.

The water temperature, ORP, $\mathrm{pH}$, and sulfide concentrations were measured at the initiation and termination of the experiments. Two $20 \mathrm{~mL}$ samples of near-bottom water ( $\sim 1 \mathrm{~cm}$ from sediment) were collected from each treatment with a syringe: one for determining water temperature, $\mathrm{ORP}$, and $\mathrm{pH}$ on our support vessel, and the other for quantifying sulfide levels in a laboratory. Water temperature and ORP were measured as previously mentioned. The $\mathrm{pH}$ was measured using a pH meter (HM-14P, DKK-TOA Inc., Tokyo, Japan). After the water samples were filtered using $0.45-\mu \mathrm{m}$ filters, the sulfide content was quantified using a modification of the methylene blue method (Cline 1969), aiming to avoid volatilization of $\mathrm{H}_{2} \mathrm{~S}$ and simplify the sampling procedure (Sakai et al. 2004).

Paired t-tests were used to detect differences in Manila clam survival, sulfide concentration, ORP, and $\mathrm{pH}$ between the algal presence and absence in the summer and autumn experiments. Effect of temperature was not tested statistically because of pseudo replication for the temperature treatment. Prior to the analyses, data for clam survival and sulfide concentration were arcsine square root and log $(\mathrm{x}+1)$ transformed, respectively. The analyses were performed for the data at the start and end of the summer and autumn experiments, and performed using R 3.3.3 (R Core Team 2017).

\section{Results}

\section{Seasonal changes in abundance of macroalgae, Manila clams, and the environment}

Bottom water temperatures ranged from $5.2^{\circ} \mathrm{C}$ in January 2013 (Site 2) to $31.1^{\circ} \mathrm{C}$ in August 2012 (Site 3), and did

Table 1. Parameter estimates and AIC for GLMMs explaining clam density by macroalgal cover (ALGcov), algal mat depth (ALGdep), water temperature (temp) and salinity (sal) during the macroalgae growing season (Jun-Oct). Models are arranged in order of increasing Akaike information criterion (AIC). $\triangle \mathrm{AIC}$ is the difference in AIC from that of the best model. * $\mathrm{P}<0.05,{ }^{* * *}: \mathrm{P}<0.001$.

\begin{tabular}{|c|c|c|c|c|c|c|}
\hline Model & Parameter & Estimate & $\mathrm{SE}$ & Z-value & AIC & $\triangle \mathrm{AIC}$ \\
\hline \multirow[t]{3}{*}{$\sim$ Algal cover } & & & & & 690.3 & 0 \\
\hline & intercept & 1.855 & 0.884 & $2.099^{*}$ & & \\
\hline & ALGcov & -2.686 & 0.247 & $-10.895 * * *$ & & \\
\hline \multirow[t]{3}{*}{ 〜Algal depth } & & & & & 707.3 & 17.0 \\
\hline & intercept & 1.180 & 0.923 & 1.279 & & \\
\hline & ALGdep & -0.044 & 0.004 & $-10.043^{* * *}$ & & \\
\hline \multirow[t]{3}{*}{$\sim$ Salinity } & & & & & 777.6 & 87.3 \\
\hline & intercept & 5.795 & 1.085 & $5.342^{* * *}$ & & \\
\hline & sal & -0.264 & 0.032 & $-8.304^{* * *}$ & & \\
\hline \multirow[t]{3}{*}{$\sim$ Water temperature } & & & & & 808.3 & 118.0 \\
\hline & intercept & -16.419 & 2.820 & $-5.821^{* * *}$ & & \\
\hline & temp & 0.661 & 0.095 & $6.956^{* * *}$ & & \\
\hline \multirow[t]{2}{*}{ Null } & & & & & 860.1 & 169.8 \\
\hline & intercept & 0.794 & 0.932 & 0.853 & & \\
\hline
\end{tabular}




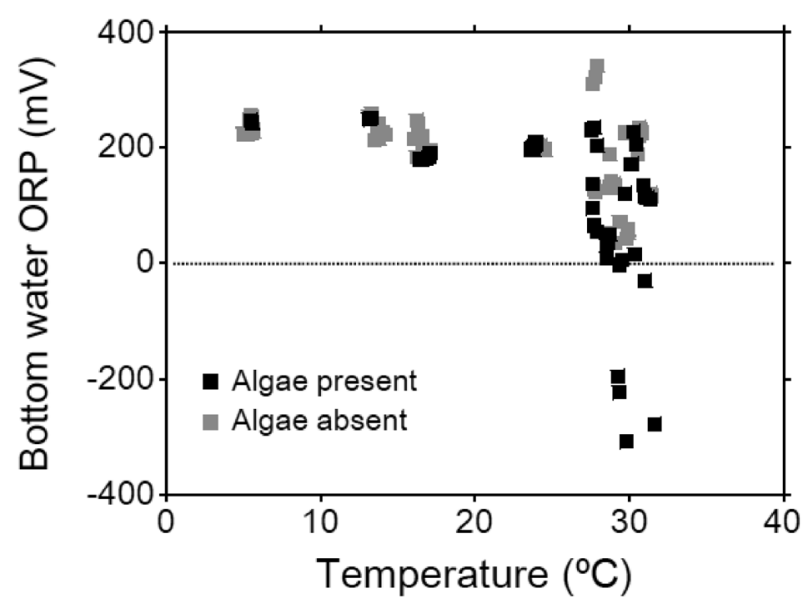

Fig. 5. Relationship between oxidation-reduction potential (ORP, $\mathrm{mV}$ ) and temperature in the bottom water in the macroalgaepresent and absent areas.

not differ by more than $1.4^{\circ} \mathrm{C}$ among sites in each month (Fig. 2A). Salinity ranged from 10.0 in July at Site 2 to 23.7 in May at Site 4 (Fig. 2B). There were substantial declines in salinity in the summer and winter owing to rain and snowfall, respectively (Fig. 2B).

Macroalgal cover and algal mat thickness increased during the summer, with peaks between July and September (Figs. 3A, B). The seasonal variations in the algal mat cover and thickness were significantly correlated $(\mathrm{r}=0.74, \mathrm{p}<0.001)$. In the peak period, large uniform mats $\left(\geq 100 \mathrm{~m}^{2}\right)$ were occasionally observed, with a thickness of $57.1 \pm 2.05$ (mean \pm SE) $\mathrm{cm}(\mathrm{n}=20)$ (Figs. 3A, B). These algal mats were temporally unstable. Indeed, even the large, uniform mats $\left(\geq 100 \mathrm{~m}^{2}\right)$ disappeared within 2 weeks of initial observation. After autumn, both algal cover and mat thickness decreased markedly and remained low until the following spring (Figs. 3A, B).

Density of Manila clams decreased during the summer months (Jun-Sep) when macroalgal cover and thickness were high (Fig. 4A). Size classes of $5-20 \mathrm{~mm}$ shell length dominated the clam population; however, new recruits (shell length $<5 \mathrm{~mm}$ ) were hardly observed (Fig. 4B). During the algae growing season (Jun-Oct), variation in clam density was better explained by macroalgal abundance (i.e., algal cover and mat thickness) when compared to other environmental variables (water temperature and salinity) in the GLMMs (Table 1). Additionally, algal cover best explained clam density variation (Table 1), with lower densities occurring with higher macroalgal cover (Figs. $3 \mathrm{~A}, 4 \mathrm{~A})$. In contrast, from autumn to the following spring, clam density increased (Fig. 4A), with new recruits (shell length $<5 \mathrm{~mm}$ ) dominating (Fig. 4B).

At some sites during the summer when the water temperature exceeded $29^{\circ} \mathrm{C}$ (Jul-Sep), the bottom water conditions in the macroalgae-present area became reducing, including a drastic reduction of ORP values to less than $-200 \mathrm{mv}$ (Fig. 5). In contrast, in macroalgae-absent areas,

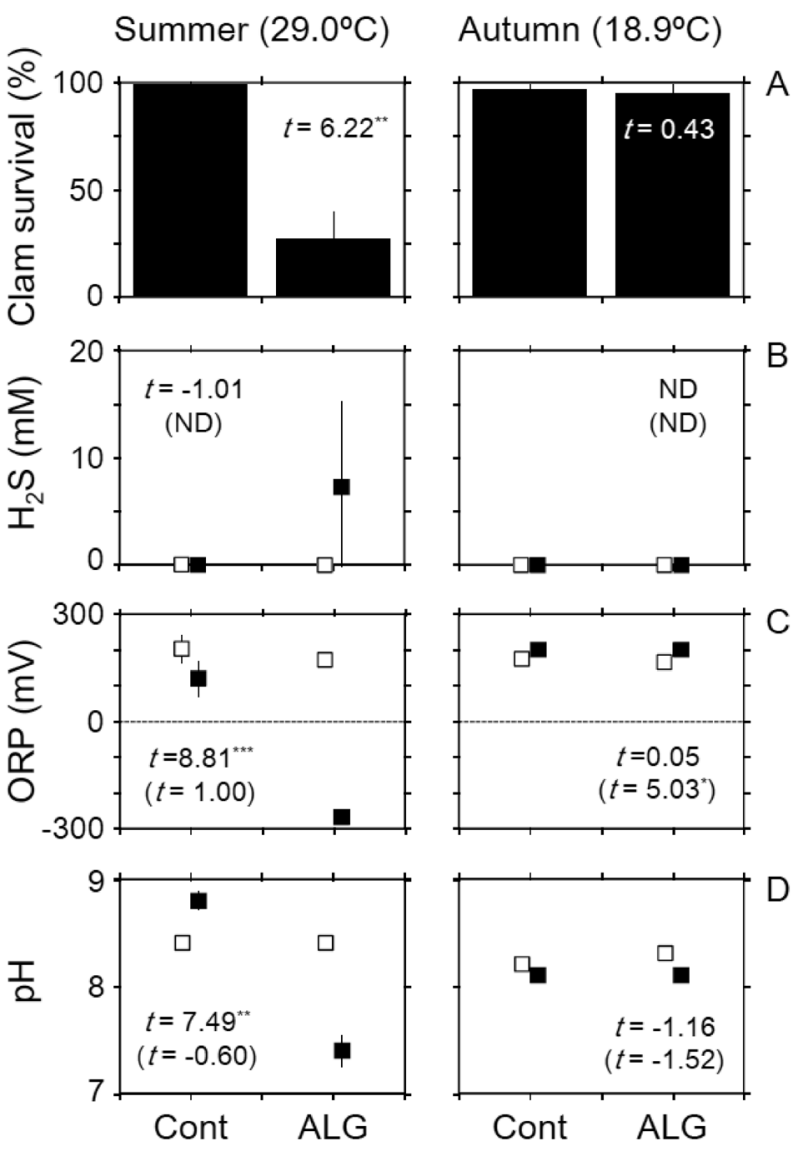

Fig. 6. Comparison of Manila clam survival (A) and sulfide concentrations (B), ORP (C), and $\mathrm{pH}(\mathrm{D})$ in bottom water between the drifting-macroalgae presence and absence treatments for the summer and autumn experiments. Open and closed squares indicate the initiation and termination of the experiments, respectively. Error bars are $\pm 1 \mathrm{SE}$ ( $\mathrm{n}=5$ each). Results of paired t-tests between the treatments at the initiation (in parentheses) and termination of each 7-day-experiment were also shown. Asterisks: ${ }^{*}: \mathrm{p}<0.05,{ }^{* *}$ : $\mathrm{p}<0.01,{ }^{* * *}: \mathrm{p}<0.001$. ND in Fig. 6B indicates "not detected".

reducing conditions were not detected even in the summer (Fig. 5). Bottom waters were oxic (ORP $>+100 \mathrm{mV})$ from the autumn to the spring (temperature $<25^{\circ} \mathrm{C}$; Fig. 5).

\section{Temperature dependency of algae-induced clam mortal-} ity and environmental variables

In the macroalgal excluding treatment, no significant clam mortality was detected in either the summer or autumn experiments (summer clam survival: $99.0 \pm 1.96 \%$ (mean $\pm 95 \% \mathrm{CI}$ ); autumn survival: $97.0 \pm 3.92 \%$ ), indicating that the fence system used to enclose and exclude drifting macroalgae did not affect clam survival.

In the summer experiment (mean water temperature: $29.0^{\circ} \mathrm{C}$ ), the 7-day survival of Manila clams was significantly lower in the macroalgal enclosure than in fences that excluded algae (Fig. 6A). At the initiation of the summer experiment, no significant differences were detected in sulfide content, ORP, or $\mathrm{pH}$ between the macroalgae-en- 
closure and exclusion treatments (Figs. 6B-D). In addition, no significant amount of sulfide was detected for either treatment (Fig. 6B), and both treatments occurred under oxic conditions (ORP $>+100 \mathrm{mV}$; Fig. 6C). At the termination of the summer experiment, sulfide content did not differ between treatments (Fig. 6B); however, ORP and $\mathrm{pH}$ were significantly lower in the algae-enclosing treatment than in the excluding treatment (Figs. 6C, D). The algal enclosure resulted in reducing conditions (ORP: $-268 \pm 3.4$ (mean $\pm \mathrm{SE}), \mathrm{n}=5$ ), whereas an oxic condition was observed in the algae-excluding treatment (ORP: $121 \pm 46.5$, $\mathrm{n}=5$ ) (Fig. 6C).

In the autumn experiment (mean temperature: $18.9^{\circ} \mathrm{C}$ ), clam survival did not differ between treatments (Fig. $6 \mathrm{~A})$; no significant mortality was detected for both treatments (macroalgae-enclosing treatment: $95.0 \pm 7.59 \%$ (mean $\pm 95 \% \quad \mathrm{CI}$ ); macroalgae-excluding treatment: $97.0 \pm 3.92 \%$ ). At the initiation of the autumn experiment, no significant differences were detected in sulfide content and $\mathrm{pH}$ (Figs. 6B, D). ORP was significantly lower in the macroalgae-enclosing treatment than in the excluding treatment (Fig. 6C); however, both treatments were under oxic conditions (ORP in algal treatment: 174 \pm 11.2 (mean \pm SE), ORP in control treatment: 164 $\pm 12.6, n=5$ each). At the termination of the experiment, sulfide content, ORP, and $\mathrm{pH}$ did not differ between treatments (Figs. 6B-D). Both treatments resulted in no accumulation of sulfide (Fig. 6B) and oxic conditions persisted (ORP $>+100 \mathrm{mV}$, Fig. 6C).

\section{Discussion}

Our field observations illustrated that Manila clam density decreased during the summer (Jun-Sep) when macroalgal cover and thickness were high. During the season, variation in clam density was better explained by macroalgal cover and thickness than by other environmental variables (water temperature and salinity). Clam density variation was best explained by algal cover. Considering algal cover was positively correlated with the thickness, it is suggested that large and thick mats of drifting macroalgae cause deleterious effects on Manila clams in Nakaumi Lagoon, as has been documented by Arroyo \& Bonsdorff (2016). However, in the present study, we could not separate the effects of macroalgal cover and thickness on clam mortality since our field census was not designed to evaluate this issue.

During the summer (water temperature $\geq 29^{\circ} \mathrm{C}$ ) when large, thick algal mats appeared and declines in clam density were observed, reducing conditions $($ ORP $<-200)$ were detected in the bottom water beneath the drifting macroalgal mats, but not above uncovered bare sandy bottoms. This suggests that the drifting macroalgae induced severe hypoxia or anoxia under the high temperature conditions. In contrast, clam density increased from the autumn to the following spring, owing to the recruitment of small-bodied new settlers when macroalgae were scarcely observed and bottom water was in oxic conditions. These results suggest that algae-induced hypoxia results in the observed summer mortality of Manila clams. The summer decrease in clam density associated with macroalgal proliferation has also been documented in previous studies for Nakaumi Lagoon (Fujikawa et al. 2000, Yamada et al. 2014), suggesting that our finding was not a specific phenomenon during the study period.

The summer adverse effects of drifting macroalgae were also detected in our field experiments: the 7-day presence of macroalgae caused markedly increased mortality in the clams, compared to those without algae at summer temperatures (7-day mean: $29^{\circ} \mathrm{C}$ ). Macroalgal mats have been acknowledged as a factor inducing widespread mortality in organisms of limited mobility, such as infaunal bivalve species (Petersen et al. 1994, Norkko et al. 2000, Marsden $\&$ Bressington 2009). The most destructive factor connected to algal mats is hypoxia or anoxia, often accompanied by the release of sulfide from sediments (Lavery \& McComb 1991, Krause-Jensen et al. 1999, Lauringson \& Kotta 2006). In the experiments, the macroalgal presence at the summer temperatures (mean \pm SE: $29.0 \pm 0.73^{\circ} \mathrm{C}, \mathrm{n}=168$ ) also caused highly reducing conditions and lowered $\mathrm{pH}$ in bottom waters, suggesting an accumulation of reduced substances beneath the algal mats. Whereas no difference in sulfide was detected between the macroalgal enclosing and excluding treatments, a significant level of sulfide accumulation was observed in two out of five macroalgal enclosures (mean \pm SE: $18.2 \pm 12.6 \mathrm{mM}, \mathrm{n}=2$ ), with lower clam survival than in the sulfide-undetected replicates $(0 \pm 0.00 \%, \mathrm{n}=2$ and $45.0 \pm 5.00 \%, \mathrm{n}=3$ in sulfide-detected and undetected replicates, respectively). In contrast, such reducing conditions were not observed in the algae-excluding treatment. In general, sulfate reduction represents the complete depletion of oxygen and the presence of truly anoxic conditions (Balzer 1984, Beck \& Bruland 2000, Middelburg \& Levin 2009). Hence, these results strongly suggest that hypoxia (even anoxia) induced by macroalgal mats was one of the underlying causes of the reducing condition in bottom waters and the increased clam mortality under the high summer temperatures. The algae-induced summer reducing condition was also found in our field census, further strengthening the experimental findings.

In contrast, when water temperature was moderate (7day mean: $19^{\circ} \mathrm{C}$ ), no significant differences in clam survival were detected between the algal enclosing and excluding treatments. At moderate temperatures, neither reducing conditions nor sulfide release from the sediment was observed even in the algal enclosure, suggesting that macroalgal mats did not induce bottom water hypoxia and hence did not result in sulfide accumulation and clam mortality. These findings were supported by our field survey, as the algae-induced reducing condition was only observed under higher summer temperatures $\left(\geq 29^{\circ} \mathrm{C}\right)$.

These results indicate that the effects of drifting mac- 
roalgae on the survival of Manila clams are not always destructive, as the occurrence of hypoxia beneath the algal mats depends on water temperature. Two reasons can be given for the temperature-dependent occurrence of hypoxia in the macroalgae-dominated ecosystem. First, water temperature affects air-sea oxygen fluxes by affecting its solubility, with a decrease in solubility at higher temperatures (Garcia \& Gordon 1992). This might contribute to the increased probability of hypoxic conditions under higher water temperatures. However, this reasoning is not conclusive, because the temperature-dependent changes in oxygen solubility should occur simultaneously in areas of both macroalgae presence and absence within the same locality. The second explanation is the temperature dependency of metabolic rates. In coastal ecosystems, changes in DO depend on the net balance between oxygen production through gross primary production (GPP) and consumption through community respiration (CR). Both GPP and $\mathrm{CR}$ are expected to increase with increasing temperatures (Brown et al. 2004), but CR is expected to show a steeper response to increased temperatures than GPP (Harris et al. 2006), suggesting that the probability of macroalgaeinduced hypoxia increases with increasing water temperature. In fact, Vaquer-Sunyer et al. (2012) found that the probability of encountering hypoxic conditions increased with increasing temperature in the macroalgae-dominated Mediterranean Bay. Thus, the temperature-dependent metabolic rates seem to largely explain the summer occurrence of algae-induced hypoxia and its adverse consequence on Manila clams.

We emphasize the importance of drifting macroalgae on inducing bottom water hypoxia and resultant Manila clam mortality in this study. Although the process is important in certain shallow and stagnant water bodies (Hauxwell \& Valiela 2004, Lauringson \& Kotta 2006), it may be less important in deeper or higher energy shallow systems. In deeper waters, stratification-induced hypoxia is important because the macroalgae most frequently occur above the halocline on euphotic shallow bottoms (Norkko \& Bondsdorf 1996a). In addition, hydrologically more-active environments are less likely to accumulate drifting macroalgae and retain it for long periods of time (Hauxwell \& Valiela 2004). It has been reported that large water flushing during the tidal cycle prevented hypoxic events and consequently allowed for the occurrence of high densities of infaunal and epifaunal invertebrates, even in a eutrophic macroalgae-proliferating ecosystem (Martinetto et al. 2010). Hence, water depth and energy regime may affect algae-induced hypoxia with more prominent effects in shallower and lower energy environments, such as semienclosed coastal Nakaumi Lagoon.

Our field census conducted in the eutrophic Nakaumi Lagoon found reducing conditions in the bottom water and a decrease in the density of Manila clams during summer when large and thick drifting macroalgae appeared. Further, our field experiment revealed that the presence of drifting macroalgae resulted in reducing conditions in the bottom water and consequent reduction in clam survival only under high water temperatures. These results strongly suggest that the summer occurrence of drifting macroalgae is a cause of coastal hypoxia. As in the lagoon, dense canopies of macroalgae are becoming a common phenomenon along the world's shorelines as a result of anthropogenic nutrient enrichment (Smetacek \& Zingone 2013). Simultaneously, global warming is progressing and forecasted to lead to an increase in the mean global temperature by $0.3-4.8^{\circ} \mathrm{C}$ by the end of the 21st century (IPCC 2013). The simultaneous progression of anthropogenic eutrophication and global warming may be enhancing the likelihood of coastal hypoxia, partly by emerging algae-induced hypoxia, with its associated adverse consequences for marine life.

\section{Acknowledgements}

We thank members of the Tottori Environmental Sanitation Research Center for assistance with field work and sorting clam samples. We also thank the Research Center for Coastal Lagoon Environments of Shimane University for the use of their facilities and members of the National Institute for Environmental Studies (NIES) for providing excellent working conditions. Two anonymous reviewers provided valuable comments on preliminary drafts of the manuscript. This research was supported in part by the Research Institute of Marine Invertebrate Foundation, the Sasagawa Scientific Research Grant from the Japan Science Society (No. 21-507) and the Center Project in NIES to KY (No. 1112AF001). We dedicate this paper to the memory of Seiji Miyawaki, 1947-2013.

\section{References}

Auffrey LM, Robinson SM, Barbeau MA (2004) Effect of green macroalgal mats on burial depth of soft-shelled clams Mya arenaria. Mar Ecol Prog Ser 278: 193-203.

Arroyo NL, Aarnio K, Mäensivu M, Bonsdorff E (2012) Drifting filamentous algal mats disturb sediment fauna: Impacts on macro-meiofaunal interactions. J Exp Mar Biol Ecol 420-421: 77-90.

Arroyo NL, Bonsdorff E (2016) The role of drifting algae for marine biodiversity. In: Marine macrophytes as foundation species (ed Olafsson E). CRC press, Taylor \& Francis group, London, pp. 100-129.

Balzer W (1984) Organic matter degradation and biogenic element cycling in a nearshore sediment (Kiel Blight). Limnol Oceanogr 29: 1231-1246.

Beck NG, Bruland KW (2000) Diel biogeochemical cycling in a hyperventilating shallow estuarine environment. Estuaries 23: 177-187.

Berglund J, Mattila J, Rönnberg O, Heikkilä J, Bonsdorff E (2003) Seasonal and inter-annual variation in occurrence and biomass of rooted macrophytes and drift algae in shallow 
bays. Estuar Coast Shelf Sci 56: 1167-1175.

Brown JH, Gillooly JF, Allen AP, Savage VM, West GB (2004) Toward a metabolic theory of ecology. Ecology 85: 1771-1789.

Burkholder JM, Tomasko DA, Touchette BW (2007) Seagrasses and eutrophication. J Exp Mar Biol Ecol 350: 46-72.

Cline JD (1969) Spectrophotometric determination of hydrogen sulfide in natural waters. Limnol Oceanogr 3: 454-458.

Coffin MRS, Knysh KM, Theriault EF, Pater CC, Courtenay SC, van den Heuvel MR (2017) Are floating algal mats a refuge from hypoxia for estuarine invertebrates? PeerJ 5: e3080, DOI: 10.7717/peerj.3080.

D’Avanzo C, Kremer JN (1994) Diel oxygen dynamics and anoxic events in an eutrophic estuary of Waquoit Bay. Estuaries 18: $131-139$.

D’Avanzo C, Kremer JN, Wainright SC (1996) Ecosystem production and respiration in response to eutrophication in shallow temperate estuaries. Mar Ecol Prog Ser 141: 263-274.

Everett RA (1991) Intertidal distribution of infauna in a central California lagoon: the role of seasonal blooms of macroalgae. J Exp Mar Biol Ecol 10: 223-247.

Fletcher RL (1996) The occurrence of "green tides"-a review. In: Marine benthic vegetation (eds Schramm W, Nienhuis PH). Springer-Verlag, Berlin, pp. 7-43.

Fujikawa Y, Mukai T, Tokiwa T, Okita S (2000) Ecological research on fishery organisms (Ruditapes philippinarum and Anadara kagoshimensis). Bull Shimane Pref Fish Exp Sta 2000: 19-27 (in Japanese).

Garcia HE, Gordon LI (1992) Oxygen solubility in seawater-better fitting equations. Limnol Oceanogr 37: 1307-1312.

Gubelit YI (2015) Climatic impact on community of filamentous macroalgae in the Neva estuary. Mar Pollut Bull 91: 166-172.

Harris LA, Duarte CM, Nixon SW (2006) Allometric laws and prediction in estuarine and coastal ecology. Estuaries Coast 29: 340-344.

Hauxwell J, Valiela I (2004) Effects of nutrient loading on shallow seagrass-dominated coastal systems: patterns and processes, In: Estuarine nutrient cycling: the influence of primary producers (eds Nielsen SL, Banta GT, Pedersen MF). Kluwer Academic Publishers, Dordrecht, pp. 59-92.

Hauxwell J, Cebrian J, Furlong C, Valiela I (2001) Macroalgal canopies contribute to eelgrass (Zostera marina) decline in temperate estuarine ecosystem. Ecology 82: 1007-1022.

IPCC (2013) Contribution of working group I to the fifth assessment report of the intergovernmental panel on climate change, In: Climate Change 2013: The Physical Science Basis (eds Stocker TF, Qin D, Plattner GK, Tignor M, Allen SK, Boschung J, Nauels A, Xia Y, Bex V, Midgley PM). Cambridge University Press, Cambridge and New York, 1535 pp.

Krause-Jensen D, Christensen PB, Rysgaard S (1999) Oxygen and nutrient dynamics within mats of the filamentous macroalga Chaetomorpha linum. Estuaries 22: 31-38.

Lauringson V, Kotta J (2006) Influence of the thin drift algal mats on the distribution of macrozoobenthos in Kõiguste Bay, NE Baltic Sea. Hydrobiologia 554: 97-105.

Lavery PS, McComb AJ (1991) Macroalgal-sediment nutrient interactions and their importance to macroalgal nutrition in a eutrophic estuary. Estuar Coast Shelf Sci 32: 281-295.

Leliaert F, Malta EJ, Engelen AH, Mineur F, De Clerck O (2008)
Qingdao algal bloom culprit identified. Mar Pollut Bull 56: 1515-1518.

Liu D, Keesing JK, Xing Q, Shi P (2009) The world's largest green-tide caused by Porphyra aquaculture. Mar Pollut Bull 58: 888-895.

Liu D, Keesing JK, He P, Wang Z, Shi Y, Wang Y (2013) The world's largest macroalgal bloom in the Yellow Sea, China: formation and implications. Estuar Coast Shelf Sci 129: 2-10.

Marsden ID, Bressington MJ (2009) Effects of macroalgal mats and hypoxia on burrowing depth of the New Zealand cockle (Austrovenus stutchburyi). Estuar Coast Shelf Sci 81: 438-444.

Martinetto P, Daleo P, Escapa M, Alberti J, Isacch JP, Fanjul E, Botto F, Piriz ML, Ponce G, Casas G, Iribarne O (2010) High abundance and diversity of consumers associated with eutrophic areas in a semi-desert macrotidal coastal ecosystem in Patagonia, Argentina. Estuar Coast Shelf Sci 88: 357-364.

Middelburg JJ, Levin LA (2009) Coastal hypoxia and sediment biogeochemistry. Biogeosciences 6: 1273-1293.

Miyamoto Y, Hatsuda A (2007) Horizontal and vertical distribution of macroalgal assemblages in modern Lake Nakaumi, a coastal lagoon. LAGUNA 14: 9-16 (in Japanese with English abstract).

Moriwaki S, Michine A (2007) Catch fluctuations in Nakaumi, estuarine inland-sea, western Japan. Bull Shimane Pref Fish Exp Sta 2007: 41-48 (in Japanese with English abstract).

Norkko A, Bonsdorff E (1996a) Altered benthic prey-availability due to episodic oxygen deficiency caused by drifting algal mats. Mar Ecol 17: 355-372.

Norkko A, Bonsdorff E (1996b) Rapid zoobenthic community responses to accumulations of drifting algae. Mar Ecol Prog Ser 131: 143-157.

Norkko A, Bonsdorff E (1996c) Population responses of coastal zoobenthos to stress induced by drifting algal mats. Mar Ecol Prog Ser 140: 141-151.

Norkko J, Bonsdorff E, Norkko A (2000) Drifting algal mats as an alternative habitat for benthic invertebrates: species specific responses to a transient resource. J Exp Mar Biol Ecol 248: 79-104.

Peterson CH, lrlandi EA, Black R (1994) The crash in suspension-feeding bivalve populations (Katelysia spp.) in Princess Royal Harbor: an unexpected consequence of eutrophication. J Exp Mar Biol Ecol 176: 39-52.

R Core Team (2017) R: A language and environment for statistical computing. $\mathrm{R}$ foundation for Statistical Computing, Vienna. Available at: http://www.R-project.org/.

Sakai S, Nakaya M, Takayasu K (2004) Hydrogen sulfide distribution in bottom and pore waters during an anoxic period in Lake Nakaumi, Japan. LAGUNA 11: 65-68.

Sakai S, Nakaya M, Sampei Y, Dettman DL, Takayasu K (2013) Hydrogen sulfide and organic carbon at the sediment-water interface in coastal brackish Lake Nakaumi, SW Japan. Environ Earth Sci 68: 1999-2006.

Smetacek W, Zingone A (2013) Green and golden seaweed tides on the rise. Nature 504: 84-88.

Sun S, Wang F, Li C, Qin S, Zhou M, Ding L, Pang S, Duan D, Wang G, Yin B, Yu R, Jiang P, Liu Z, Zhang G, Fei X, Zhou M (2008) Emerging challenges: Massive green algae blooms in the Yellow Sea. Nature Precedings. Available at: http://dx.doi. 
org/10101/npre.2008.2266.1. (Posted on 10 September 2008)

Tezuka N, Kamimura S, Hamaguchi M, Saito H, Iwano H, Egashira J, Fukuda Y, Tawaratsumida T, Nagamoto A, Nakagawa K (2012) Settlement, mortality and growth of the asari clam (Ruditapes philippinarum) for a collapsed population on a tidal flat in Nakatsu, Japan. J Sea Res 69: 23-35.

Tyler RM, Brady DC, Targett TE (2009) Temporal and spatial dynamics of diel-cycling hypoxia in estuarine tributaries. Estuaries Coast 32: 123-145.

Valiela I, McClelland J, Hauxwell J, Behr PJ, Hersh D, Foreman K (1997) Macroalgal blooms in shallow estuaries: Controls and ecophysiological and ecosystem consequence. Limnol Oceanogr 42: 1105-1118.

Vaquer-Sunyer R, Duarte CM, Jordà G, Ruiz-Halpern S (2012) Temperature dependence of oxygen dynamics and community metabolism in a shallow Mediterranean macroalgal meadow (Caulerpa prolifera). Estuaries Coast 35: 1182-1192.

Yamada K, Miyamoto Y, Fujii C, Yamaguchi K, Hamaguchi M (2014) Vertical zonation and aggregated distribution of the Manila clam on subtidal sand flats in a coastal brackish lagoon along the Sea of Japan. Mar Ecol 35: 308-318.
Yamaguchi K, Kurata K, Sonoda T, Seto K (2013) Bivalve community structure and environmental changes of a brackish lagoon divided by reclamation dikes in lake Nakaumi, Southwest Japan. Jpn J Benthol 67: 82-95 (in Japanese with English abstract).

Yamamuro M, Hiratsuka J, Ishitobi Y (2000) Seasonal change in a filter-feeding bivalve Musculista senhousia population of a eutrophic estuarine lagoon. J Sea Res 26: 117-126.

Yamamuro M, Hiratsuka J, Ishitobi Y, Hosokawa S, Nakamura Y (2006) Ecosystem shift resulting from loss of eelgrass and other submerged aquatic vegetation in two estuarine lagoons, Lake Nakaumi and Lake Shinji, Japan. J Oceanogr 62: 551558.

Yasugi S, Nakamura M, Miura S, Nakao S (1999) Successional changes of macrobenthos community on the artificial bottom in Lake Nakaumi. Aquacult Sci 47: 181-190 (in Japanese with English abstract).

Ye NH, Zhang XW, Mao YZ, Liang CW, Xu D, Zou J, Zhuang ZM, Wang QY (2011) 'Green tides' are overwhelming the coastline of our blue planet: taking the world's largest example. Ecol Res 26: 477-485. 